\title{
SOME FEATURES OF BARLEY AND OATS PROCESSING
}

\begin{abstract}
It is proved the high effectiveness of using naked oats varieties Salomon and Samuel and hull-less barley variety Achilles as raw material for production new groats products with high biological value. Researched modes of pearling, water heat treatment and its impact on yield of pearled and flaked groats. The technological scheme of processing hull-less barley and naked oats for producing groats, flakes, mixtures of groats and flakes were developed.

Technology includes grain cleaning stage, grain water heat treatment, pearling, sorting of pearling products, pearled groat water heat treatment, mixing, flaking, drying, and control of end products. Studied hull-less barley characterized by high protein content $14,615,8 \%$ and $\beta$-glucans $-6,8-7,4 \%$, has same to conventional dehulled grain mass fraction of lipids 2,1-3,8\% and starch57,6-60,5\%, low ash content 2,3-2,7\%. Naked oats grain traditionally characterized by high mass fraction of lipids - 6,0-6,3\%, high mass fraction of protein - 14,9-15,4\% and Bglucans - 6,4-6,9\% close to conventional dehulled grain mass fraction of starch-59,3-61,6 $\%$ and ash-2,1-2,3\%. It was found that the technologically expedient moisture content of hull-less barley and naked oats before pearling is $12-13 \%$.

In the pearling the grain with this humidity depending on the duration of pearling yield of groat estimated to range between $6796 \%$. Increasing moisture content of grain before pearling to $14.0 \%$ does not significantly change the limits of yield values, and pearling grain with low moisture content of $10.5 \%$ leads to excessive grinding and formation of a significant amount of by-products and waste in the form of fine particles and husking bran.Technologically expedient moisture content of naked oats pearled groat before steaming stage are $15 \%$ and the vapor pressure in steamer of $0.10 \mathrm{MPa}$. For the pearled barley groat most appropriate moisture content of before steaming is $20 \%$ and the vapor pressure in steamer of $0.10 \mathrm{MPa}$.Steaming in this mode allows to obtain flaked groats with yield at 84 to $93 \%$.
\end{abstract}

Key words: naked oats, hull-less barley, groats, flakes, mixtures of groats and flakes, modes of processing, scheme of processing ,chemical composition.

\section{Introduction. Formulation of the problem}

The peculiarity of the groats production is the presence of a wide range of raw materials. In cereal plants traditionally processing eight major cereal crops: rice, millet, buckwheat, oats, barley, corn, wheat and legumes - peas, and well as small quantities of sorghum, lentils and chickpeas.

Barley is an important hulled crop, which is widely used in the food-processing industry - in the production groats, flakes, instant food, and beer. Flour derived from barley use in mixtures with wheaten in bakery and confectionery industry, starch and syrup industry use barley for production starch. Due to significant amount of protein, $\beta$-glucans and vitamins its use to production of food products with specific and functional purpose [1, $2,3,4]$.

The main range of products obtained by processing barley grain of groats purpose (first class grain according to the DSTU 3769) is two kinds of groats pearl barley and crushed pearl barley.

Based on the analysis of existing technologies of barley processing into groat products it can be concluded that the production of barley foods requires the use of four dehulling systems, three pearling systems, three polishing systems, five sorting systems and seven controlling systems at different stages in air separators, for producing of crushed pearl barley requires the use of four systems for grinding of pearl barley and additional polishing system for medium fractions of crushing groat [5].

Yield of pearl barley does not exceed $45 \%$, crushed pearl barley $-65 \%$. Complex technological pro- cess leads to the fact that from barley grain removed significant portion of useful substances for the human body - proteins, lipids, fiber, minerals. For example in processing of pearled barley $74 \%$ of the proteins, $85 \%$ of the fat, $97 \%$ fiber and $88 \%$ of the minerals that are present in unprocessed covered barley grain are removed [6].

In Ukraine over the past decade products of oats processing become traditional for the majority of population. Oats crop among other cereals characterized by the most valuable chemical composition - high content of protein, fat, digestible carbohydrates, vitamins, minerals etc. In oats grain are present all essential for human body amino acids which indicates the high biological value of products derived from it. Oats grain and its products contain a high mass fraction of fat $(5.0 \ldots 7.0 \%)$ while the mass fraction of important for the human body polyunsaturated fatty acids is $70-80 \%$, which suggests a high biological effectiveness of oat grains. Among the carbohydrate complex, except starch and other substances great value has non starch polysaccharide $\beta$-glucan. This substance refers to the soluble fibers which have the ability to regulate degree of cholesterol and sugar in blood and affect to regulation of weight, etc., so is a necessary ingredient in the human diet. According to various sources oatmeal among other cereals and cereal products on the content of dietary fiber holds one of the leading positions having them mass fraction of 7-8 \% [7-15].

Processing oats grain by existing traditional technologies through the use of complex and extended of technological process does not allow using all potential 
inherent to oats crop. Standard products of processing oats in Ukraine are not crushed oats groat of which during further processing produces flaked groats, flakes "Hercules", "Pelyustkovi". Separate oat products are flakes "Extra" and "Tolokno" (special prepared oats flour). Not crushed oats groats are products derived from whole kernel they are divided into grades by quantitative content of benign and crushed kernel and presence in the product not hulled grain. Flaked groats and all kinds of oats flakes through the passage during their producing additional special treatment can be referred to the instant foods.

Numbers of flakes "Extra" proportional to the size and shape of previously prepared raw materials due to what they have a high uniformity which is provided by passage and overtail of defined number of sieve. "Tolokno" by its properties are very important food product. As stand-alone product "Tolokno" widely used in dietary nutrition. "Tolokno" and different kinds of oat flour due to the absence of gluten as separate products is almost not applicable but in mixtures with wheat flour oats flour widely used in the baking industry in the production of bread bakery and confectionery products and as in improver in other areas of food processing industry [6].

The existing technologies do not allow getting a high yield of finished products by processing of oats, which does not exceed 55-65\% even when using the most modern hull oat varieties with improved properties. Also there is need for warehousing, storage and utilization a significant amount of husk the amount of which, depending on the varietal characteristics of processed grain, can reach $20-40 \%$ [16-17].

The technological processes of processing hulled oats are amongst the most difficult in cereal production include water heat treatment by method of hot conditioning, hulling in several systems, sorting of hulling products, complex groats separation stage, pearling etc, all this leads to significant energy costs of technology and the need for large production areas for its implementation.

Today in the world there is a transition to a less complex and more energy efficient technologies which allows obtaining products with high yield and nutritional value. The basis for the creation of new food products with improved properties are new specially bred by breeders grain crops. Among which can identified hullless varieties of barley and oats [18-22].

Hull-less barley has a high groats processing potential and almost total absence of hard floral hulls, allows to its processing in cereal products by reduced technological process. Y.V. Kolmakov and N.I. Anyskov [22] studying the processing of barley grains found that in its processing yield of groats can reach 79-84\%, while L.V. Rukshan [23] and others found that the main stages of processing hull-less barley into groats are grain clearing stage, water heat treatment by method of cold conditioning and pearling.

The main advantages of hull-less barley are excellent chemical composition. Studying the different varieties of barley C.V. Helm and A. de Francisco [24] showed that hull-less barley grain has a mass fraction of protein $13-16 \%$ that prevails by its number of hulled grains 11-13\%. This allows getting more useful and quality products with high protein content during processing these grains which makes it attractive raw material for the food industry. Another important factor for cereals, which are used to create products with special purposes (dietary, medical, functional) is the presence of non-starch polysaccharide $\beta$-glucan.

It is known that among other crops, barley grain contains the largest mass fraction of this substance $3,5-5,7 \%$, at the same time research findings Y.L. Yin and others [25] show more mass fraction of $\beta$ glucans in hull-less barley grain 4,0-7,0 \%. As revealed research conducted by A.A. Gryaznov and others [26] hull-less barley contains more vitamin E (44.96 mg / kg) and B5 $(50.31 \mathrm{mg} / \mathrm{kg})$ and has a slightly lower content of vitamins B1 $(2.45 \mathrm{mg} / \mathrm{kg})$ and B2 $(0.81 \mathrm{mg} / \mathrm{kg})$ compared to hulled grain. Considering it hull-less barley grain are widely used for the production of daily food products in Japan, China, Pakistan, Nepal, Afghanistan, while in Europe this more grain used to produce functional products.

In Ukraine hull-less barley grain is a relatively new culture which is not widely used for production of groats products. Breeding of food varieties of hulless barley engaged in Odessa Plant Breeding and Genetics Institute, where under the guidance of D.Sc. Rybalka A.I. two modern food cultivars of hull-less barley «Achilles» and «Gladiator» were bred.

However, despite the availability of this type of grain a major obstacle of its use in domestic groats industry there are no regulations for its processing. Analysis of groat enterprises has shown that the application of regimes process, which recommended by current regulations only by exclusion of dehulling stage leads to slight improvement in production, especially with regard to increasing yields and chemical composition and in the aggregate cannot use all the potential inherent into grain. Naked oats despite its presence in the country for 10-15 years is not used for food production. Existing recommendations do not include features of technological properties, presence of hulled grain, and chemical composition. All of this leads to the fact that an extremely high potential cereal culture processed in groats and groats products, whose quality properties do not conform to regulated standards or conversely produce regulated products, with low yield and relatively low value.

Today in Ukraine has a problem with range of functional cereal products. Conducted analysis of the literature data shows that the most suitable raw material for development groats products with functional purpose are hull-less barley and naked oats grain. Their use will allow getting functional products with increased yield under reduced technological process which is the actual problem of grain-processing industry. Development of technologies for new products based on a rational use of natural potential of grain such as high nutritional value for the human body are the modern trend of grainprocessing industry.

\section{Material and methods}

The promising and the most common cultivars of naked oats and hull-less barley grown in our country were selected for the researches. Two samples of naked 


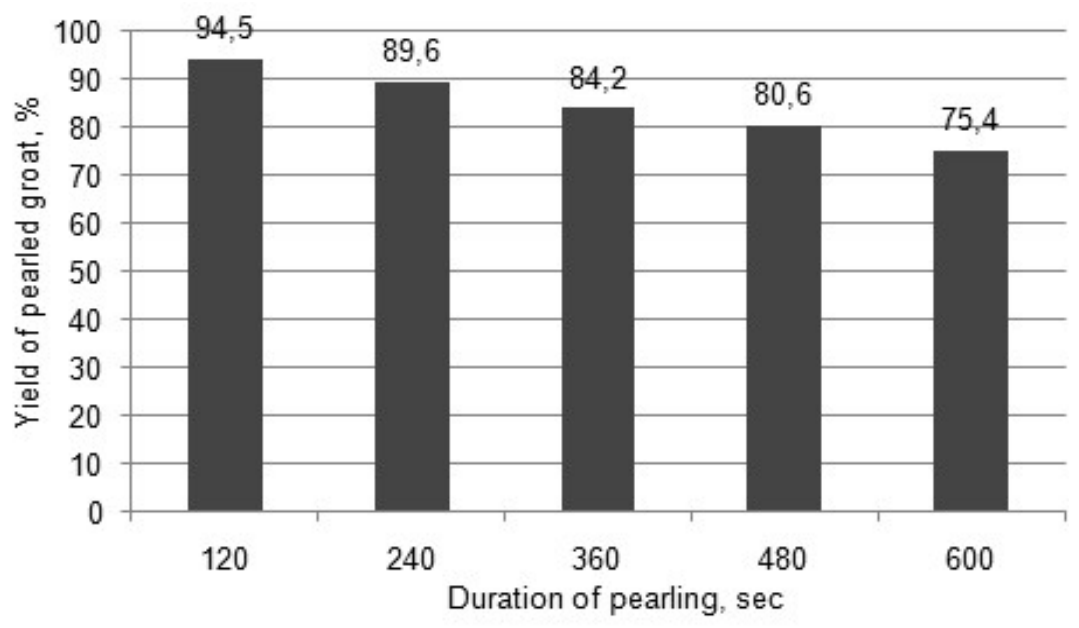

Fig. 1 - Influence intensity of pearling hull-less barley with a moisture content $12 \%$ on yield of groat

oats cultivars «Salomon» and Samuel were cultivated in Ukraine in 2016...2018 years. Cultivar of hullless barley «Achilles» was cultivated in Odessa region, Ukraine in 2016...2018 years.

Before pearling stage samples of naked oats and hull-less barley moistening to $12-14 \%$ and then tempering 8-12 hrs. Pearling of oats and barley were carried out in the laboratory dehulling and pearling which used method of intensive abrasion. Samples of naked oats grain pearled for 30 to $180 \mathrm{~s}$ with the change interval 30 seconds, hull-less barley - for 120 to $600 \mathrm{~s}$ with the change interval 120 seconds.

Samples of pearled groats were moistening to 15-17\% (for oats) and 20-22\% (for barley) and then tempering for $1-4 \mathrm{hrs}$.

Steaming of oats and barley groats were carried out in the laboratory steamer of periodic action VK-30. Specially prepared sample of the studied material was filled in the special cartridge and placed in steamer. With help of the intake and exhaust valves the pressure and time of steaming were regulated. Groat was steamed at $0,10 \mathrm{MPa}$ for $120-300 \mathrm{sec}$ and then sent to the flaking stage.

Flaking was carried out in the laboratory mill «Nagema» which includes a roller mill with two pairs of rollers $150 \mathrm{~mm}$ length and $220 \mathrm{~mm}$ in diameter. Working gap set $0.3-0.5 \mathrm{~mm}$.

Drying of the groat and flaked groats after steaming and flaking were carried out in the laboratory dryer which works on a "fluidized bed". Mode of operation of the dryer (degree of removal of excessive moisture) was regulated by temperature changes drying agent (air) and time of the grain location in the working area of the dryer. Groat and flakes were dried to a moisture content of $14 \%$.

\section{Results and discussion}

Studied hull-less barley characterized by high protein content $14,6-15,8 \%$ and $\beta$-glucans $-6,8-7,4 \%$, has same to conventional dehulled grain mass fraction of lipids $2,1-3,8 \%$ and starch $-57,6-60,5 \%$, low ash content $2,3-2,7 \%$. Naked oats grain traditionally characterized by high mass fraction of lipids - 6,0-6,3\%, high mass fraction of protein - 14,9-15,4\% and $\beta$-glucans -
$6,4-6,9 \%$ close to conventional dehulled grain mass fraction of starch - 59,3-61,6 $\%$ and ash $-2,1-2,3 \%$ (tabl. 1).

Analysis of the data shows that during processing investigated samples of hull-less barley and naked oats is to possible obtain as standardized groats products and at specifically defined modes to carry out their processing into groats, flakes and flours with a high content of bioactive substances.

Pearling is the main technological operation during processing of hullless barley and naked oats. This operation allows obtaining high yield of a kernel and also ensures the production of products with regulated indicators. The shape of barley and oats contributes to irregular distribution of grain in the working zone of pearler which contributes to the formation fine particles, which are breaking away from grains. Pearling stage realized by method of intensive abrasion impact on redistribution anatomical parts of the grains in which placed the appropriate components of the chemical composition of grains. Therefore, at the pearling stage besides removing of outer layers of grains that contain mostly hard to digest cellulose also occurs partial removal protein, starch, $\beta$-glucans, etc. Husking bran of barley and oats obtained after pearling usually characterized by high nutritional value, formed by the high amount of protein, $\beta$-glucans, starch, lipids, and vitamins which means that these valuable substances eliminated from groats and its biological value decreases.

Tabl. 1 - Some indicators of chemical composition of naked oats and hull-less barley

\begin{tabular}{|c|c|c|c|c|}
\hline \multirow{2}{*}{$\begin{array}{l}\text { Mass fraction } \\
\text { of chemical } \\
\text { substances } \%\end{array}$} & \multicolumn{2}{|c|}{ Samples } & \multicolumn{2}{|c|}{ Conventional } \\
\hline & $\begin{array}{c}\text { naked } \\
\text { oats }\end{array}$ & $\begin{array}{c}\text { hull-less } \\
\text { barley }\end{array}$ & $\begin{array}{c}\text { oats } \\
\text { (kernel) }\end{array}$ & \begin{tabular}{|c|} 
barley \\
(kernel)
\end{tabular} \\
\hline Protein & $14,9-15,4$ & $14,6-15,8$ & 12,3 & 16,1 \\
\hline Lipids & $6,0-6,3$ & $2,1-3,8$ & 6,0 & 2,8 \\
\hline Starch & $59,3-61,6$ & $57,6-60,5$ & 59,6 & 58,6 \\
\hline$\beta$-glucans & $6,4-6,9$ & $6,8-7,4$ & 5,2 & 7,2 \\
\hline Ash & $2,1-2,3$ & $2,3-2,7$ & 2,2 & 2,4 \\
\hline
\end{tabular}

Therefore, the development of functional foods from hull-less barley and naked oats the main objective was to determine the modes at which groats and flakes having acceptable consumer properties retain the maximum amount of biologically active substances.

It was found that the technologically expedient moisture content of hull-less barley and naked oats before pearling is $12-13 \%$. In the pearling the grain with this humidity depending on the duration of pearling yield of groat estimated to range between $67-96 \%$. Increasing moisture content of grain before pearling to $14.0 \%$ does not significantly change the limits of yield values, and pearling grain with low moisture content of $10.5 \%$ leads to excessive grinding and formation of a significant amount of by-products and waste in the form of fine particles and husking bran. 


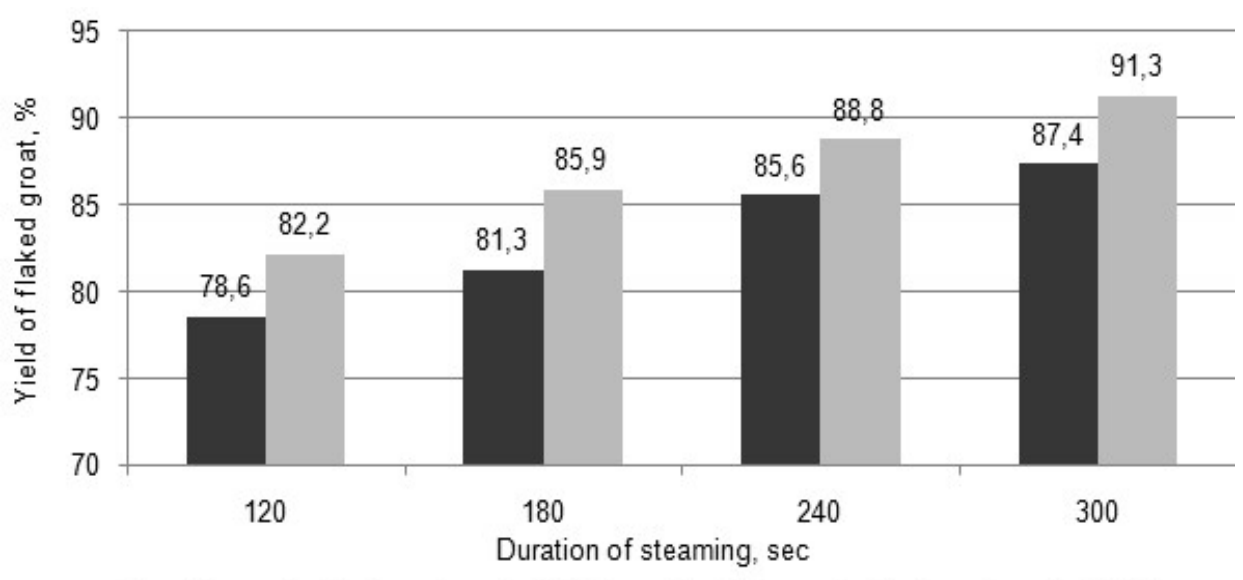

- moister content before steaming $20 \% \quad$ moister content before steaming $22 \%$

Fig. 2 - Influence of moistening to 20 and $22 \%$ and steaming at $0.10 \mathrm{MPa}$ of hull-less barley groat on yield of flaked groat

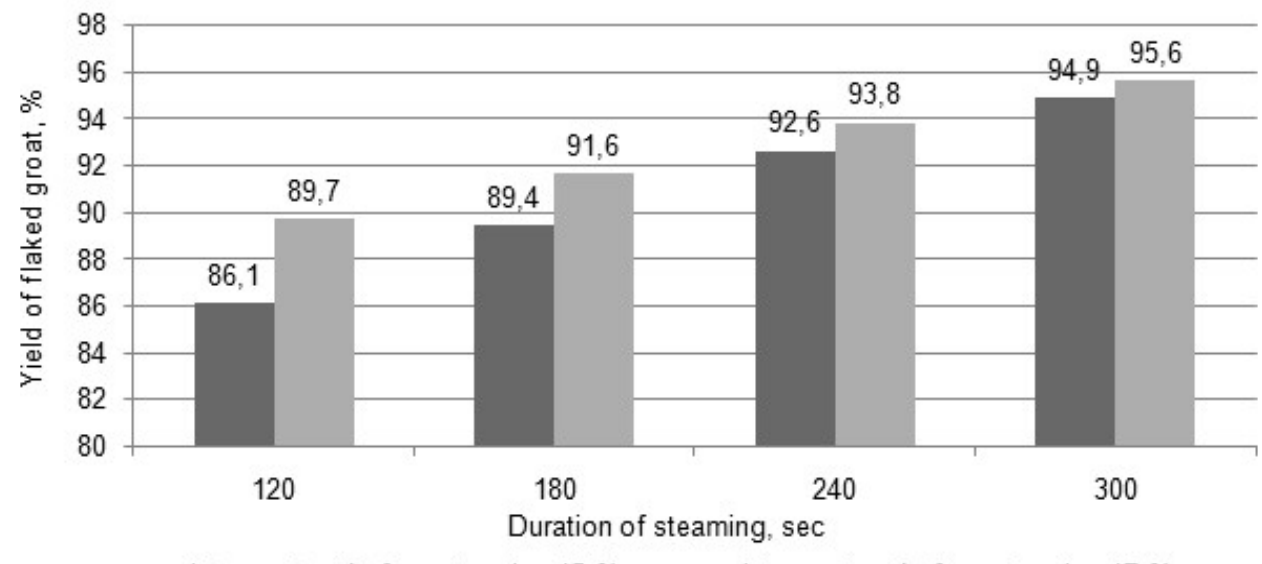

- moister content before steaming $15 \% \quad$ moister content before steaming $17 \%$

Fig. 3 - Influence of moistening to 15 and $17 \%$ and steaming at $0.10 \mathrm{MPa}$ of naked oats groat on yield of flaked groat
$94 \%$ for naked oats) and increased by $1.5-2.0 \%$ mass fraction of protein and $\beta$ glucans at the same time ash content in pearled groats increased slightly and include 2.3-2.4\% for barley and 2.2$2.3 \%$ for oats.

At the next stage modes of preparation of pearled groats for flaking was investigated. The results of research of influence of moistening to 20 and $22 \%$ of barley groats and to 15 and $17 \%$ of oats groats and steaming at $0.10 \mathrm{MPa}$ on yield of flaked groat are presented in Figure 2-3.

Analysis of the data shows that preparation of pearled groat to flaking with a soft modes of water-heat treatment allows to produce flaked groats with high yield.

For these modes technologically expedient moisture content of naked oats pearled groat before steaming stage are $15 \%$ and the vapor pressure in steamer of 0.10 $\mathrm{MPa}$. Steaming in this mode allows to obtain flaked groats with yield at 84 to $93 \%$. Under the preliminary organoleptic assessment of obtained in this
In the pearling stage of hull-less barley and naked oats realized by method of intensive abrasion due to the extracting a particle bran parts redistribution of mass fraction of chemical elements are observed.

Depending on the studied mode of pearling were observed overall reduction of mass fraction of ash (in oats grain from 2.4 to $1.4 \%$, grain barley grain from to) witch explained by removing high in ash outer layers of grain and also mass fraction of protein (in oats grain from 15 to $10 \%$, grain barley grain from to) and the mass fraction of $\beta$ glucans (in oats grain from 7 to $3 \%$, grain barley grain from to) witch explained by irregular distribution of grain in the working zone of pearler and in accordance with uneven degree of removal outer layers from grain, removing a certain part of the upper layers of the grain endosperm containing a certain amount of protein and $\beta$ glucans respectively.

Regardless of the studied mode of pearling were observed in the pearled barley and oats groat were observed increasing the mass fraction of starch (in oats grain from 60 to $67 \%$, grain barley grain from to) witch explained by increasing of the mass fraction of endosperm when outer layers from grain were removed.

Analysis of the data shows that pearling of hullless barley and naked oats with moisture content of 12 $13 \%$ with milder modes allows obtaining pearled groat with increased yield (75-94 \% for hull-less barley та 84- mode flaked groat it can be attributed to classical flaked products.

For the pearled barley groat most appropriate moisture content of before steaming is $20 \%$ and the vapor pressure in steamer of $0.10 \mathrm{MPa}$. Steaming in this mode allows to obtain flaked groats with yield at 78 to $91 \%$. By organoleptic assessment these products represent a flaked barley.

Increasing vapor pressure and humidity pearled groat at the stage of their preparation for flaking will increase yield of flaked products but by more pressure and humidity in the pearled groats will take place denaturation of the protein, process of hydrolysis of starch, reduction of $\beta$-glucans and vitamins.

Analysis of the data shows that preparation of pearled groat to flaking with a soft modes of water-heat treatment allows to produce flaked groats with higher mass fraction of protein $12-14 \%$ and $\beta$ glucans $-4,0-5,5 \%$ compared to traditional products.

On sorting stage plansifter set sieves $1,8-1,6 \times 20$ $\mathrm{mm}$ overtail of witch removed whole pearled groats, passage of this sieve are a mixture of particles of crushed kernels and husking bran. Separation of which conducted at sieves № 080-060 $\mathrm{mm}$ by passage of this sieve obtained husking bran, by overtail - particles of crushed kernels. Whole pearled groats additional control to the residues of husking bran by passage of through a system 
of air separators.

On the next stage at producing of mixed groats conduct mixing of pearled groats of hull-less barley and naked oats in given mass fraction and send mixture to water heat treatment stage. The aims of this stage are reducing microbial contamination on surfaces of groats and provision of product characteristic organoleptic properties. At this time conducted researches has shown that for the production of products with high nutritional value is also necessary to soften modes of water heat treatment.

Given this the mixture of pearled groats of hullless barley and naked oats sent to steamer of periodic action where it steamed with vapor pressure of $0.05-0.15$ $\mathrm{MPa}$ for 2-4 min.

This mode ensures minimal loss of protein and $\beta$ glucans there is no browning of groats which is typical for more hard modes of water heat treatment while by organoleptical characteristics - odor and taste the resulting product fully complies the traditional products.

After steaming groats are sent to drying. The given technological operation expediency in dryers with temperature drying agent of $40-60{ }^{\circ} \mathrm{C}$ which will also reduce the effect of temperature on changes in the biochemical composition of groats. Groats dried to moisture of 12$14 \%$ and sent to the control which conducted on one system of air separators where conduct removal of residues of husking bran. Before packing groats are required for control in magnetic separators.

For the production of a mixture of flakes whole pearled groats after pearling sent to water heat treatment. This stage in the production of flakes carried out by a combined structure of cold and hot conditioning the main purpose is to provide plastic properties of groats. Before steaming pearled naked oats groats moistening to $15-17 \%$ and sent to tempering for 2-3 hrs, hull-less barley pearled groats moistening to $20-22 \%$ and tempering for $2-4 \mathrm{hrs}$.

After that, in a given mass fractions carried out forming of mixture which is sent to steaming. Before flaking the mixture is steamed in the vapor pressure of 0.10 -
0.15 $\mathrm{MPa}$ for 4-5 min and tempering 7-9 min. Flaking conducted at flaking machine on ribbed rolls which provides the formation of microcracks on the surface of flaked groats and allow accelerate cooking time of the resulting product. Obtained mixture of flaked groats by organoleptical characteristics fully complies the traditional products.

To removed particles of crushed kernels and husking bran which are formed in small quantities at flaking mixture of flaked groats sieved. Sifting is carried out in plansifter while by overtail of sieve $1,4 \times 20 \mathrm{~mm}$ obtained flaked groats, which sent for further processing, by passage of this sieve and overtail of sieve № 063 carried out removal of particles of crushed kernels, by passage of sieve № 063 carried out removal of husking bran. Flaked groats dried at belt dryer at temperature of drying agent 40-60 ${ }^{\circ} \mathrm{C}$ to moisture content of $13-14 \%$. After this flaked groats sent for magnetic control and packaging.

\section{Conclusion}

It is proved the high effectiveness of using naked oats varieties Salomon and Samuel and hull-less barley variety Achilles as raw material for production new groats products with high biological value.

The feature of the developed scheme is significant, in comparison with existing technologies of barley and oats processing, reducing of the technological process - no energy-intensive stages of dehulling, sorting of dehulled products, groats separation stage, pearling using several systems which allows to carry out full cycle production at the plant with low productivity. At this use as raw materials of hull-less barley and naked oats at the recommended modes can increase yield of pearled and flaked groats at 1.5-1.7 times in compared to processing of conventional varieties.

Resulting products through the use of soft modes of pearling and water heat treatment characterized by high nutritional value - have a greater proportion of protein and $\beta$-glucans.

\section{REFERENCES}

1. Pomeranz, Y., \& Shands, H. L. (1974). Food uses of barley. Critical Reviews in Food Science \& Nutrition, 4(3), 377-394.

2. Evdokhova, L.N., \& Rukshan, L.N. (2012). The use of barley flour to create a flour confectionery health improving orientation. Pratsi Tavriyskogo state agrotechnology university, (12, t. 2), 203-213.

3. Kurochkin, A. A., Shaburova, G. V., \& Novikov, V. V. (2006). Use of extruded barley in brewing. Beer and beverages, (5)., 16-17.

4. Pavlovskaya, N. E., Kostromicheva, E. V., Kuleshova, E., Gorkova, I. V., \& Gagarina, I. N. (2012). Barley source of antibiotics. Journal of Agricultural Science, 37 (4), 70-72.

5. Kroshko, GD (1998). Rules for organizing and maintaining the technological process at the mill factories. $K$.: WIPOL.

6. Pomeranz, Y. (1991) Functional Properties of Food Components. San Diego, CA: Academic Press

7. Kaukovirta-Norja, A., Wilhelmson, A., \& Poutanen, K. (2004). Germination: a means to improve the functionality of oat.

8. Hager, A. S., Taylor, J. P., Waters, D. M., \& Arendt, E. K. (2014). Gluten free beer-A review. Trends in Food Science \& Technology, 36(1), 44-54.

9. Schnitzenbaumer, B., Kaspar, J., Titze, J., \& Arendt, E. K. (2014). Implementation of commercial oat and sorghum flours in brewing. European Food Research and Technology, 238(3), 515-525.

10. Önning, G., Wallmark, A., Persson, M., Ảkesson, B., Elmståhl, S., \& Öste, R. (1999). Consumption of oat milk for 5 weeks lowers serum cholesterol and LDL cholesterol in free-living men with moderate hypercholesterolemia. Annals of Nutrition and Metabolism, 43(5), 301-309. 
11. Gambuś, H., Gibiński, M., Pastuszka, D., Mickowska, B., Ziobro, R., \& Witkowicz, R. (2011). The application of residual oats flour in bread production in order to improve its quality and biological value of protein. Acta Scientiarum Polonorum Technologia Alimentaria, 10(3), 317-325.

12. Marshall, A., Cowan, S., Edwards, S., Griffiths, I., Howarth, C., Langdon, T., \& White, E. (2013). Crops that feed the world 9. Oats-a cereal crop for human and livestock feed with industrial applications. Food Security, 5(1), 13-33.

13. Eliasson, A. C. (2006). Carbohydrates in food. CRC press.

14. Chu, Y. (Ed.). (2013). Oats nutrition and technology. John Wiley \& Sons.

15. Hamaker, B. R. (Ed.). (2007). Technology of functional cereal products. Elsevier.

16. Sots, S.M. Evaluation of some technological factors of Ukrainian naked oats and barley affecting on its processing to food products http://pscipub.com/Journals/Data/JList/Scientia\%20Agriculturae/2014/Volume\%208/Issue\%201/8.pdf

17. Yegorov, G.A. (1985) Tekhnologicheskiye svoystva zerna (Technological properties of the grain). - M.: Agropromizdat

18. Steele, K., Dickin, E., Keerio, M. D., Samad, S., Kambona, C., Brook, R., ... \& Frost, G. (2013). Breeding lowglycemic index barley for functional food. Field crops research, 154, 31-39.

19. Peltonen-Sainio, P., Kirkkari, A. M., \& Jauhiainen, L. (2004). Characterising strengths, weaknesses, opportunities and threats in producing naked oat as a novel crop for northern growing conditions.

20. Yalcin, E., Celik, S., Akar, T., Sayim, I., \& Koksel, H. (2007). Effects of genotype and environment on $\beta$-glucan and dietary fiber contents of hull-less barleys grown in Turkey. Food Chemistry.

21. Batalova, G. A. (2014). Prospects and results of selection of bare oats. Leguminous and cereal crops, (2 (10)).

22. Kolmakov, Yu. V., \& Aniskov, N. I. (2009). Evaluation and quality requirements for grain naked grains of barley. Agrarian Bulletin of the Southeast, (3), 21-23.

23. Rukshan, L.V., Matveeva, A.V., \& Vetoshkina, A.A. Technology products from bare barley. Electronic resource] .- access mode: http: // gendocs. com / docs / 7/6320 / conv_3 / file3. pdf \# page 25.

24. Helm, C. V., \& Francisco, A. D. (2004). Chemical characterization of Brazilian hulless barley varieties, flour fractionation, and protein concentration. Scientia Agricola, 61(6), 593-597.

25. Yin, Y. L., Baidoo, S. K., Schulze, H., \& Simmins, P. H. (2001). Effects of supplementing diets containing hulless barley varieties having different levels of non-starch polysaccharides with $\beta$-glucanase and xylanase on the physiological status of the gastrointestinal tract and nutrient digestibility of weaned pigs. Livestock Production Science, 71(2-3), 97-107.

26. Gryaznov, A. A. (2015). Barley barley varieties in poultry feeding. Livestock and veterinary medicine, (2 (17)). Zhang, J. Functional barley rice noodle and making method thereof / J. Zhang, et al. // [Електронний реcypc]. - режим достуny: http://www.google.com/patents/CN102067965A?cl=en

УДК 664.78.014

С.М. Соц, канд. техн. наук, доцент, E-mail: sotsserega@gmail.com I.О. Кустов, канд. техн. наук, ст. викладач, E-mail: i.kustov1988@gmail.com Ю.Я. Кузьменко, канд. техн. наук, асистент, E-mail: kuzmenko.y89@gmail.com Кафедра технологї переробки зерна,

\section{Одеська наџіональна академія харчових технологій, вул. Канатна, 112, Одеса, 65039, Україна ОСОБЛИВОСТІ ПЕРЕРОБКИ ЗЕРНА ЯЧМЕНЮ І ВІВСА}

\section{Анотація}

Доведено високу ефективність використання голозерного вівса сортів Саломон та Самуель та зерна голозерного ячменю сорту Ахіллес в якості сировини для виробництва нових круп'яних продуктів з підвищеною біологічною иінністю. Досліджено режими шліфування, воднотеплової обробки та їх вплив на вихід шліфованого та плющеного ядра. Розроблено технологічну схему переробки голозерного ячменю та голозерного вівса для виробництва крупи, пластівців, сумішей крупи та пластівців. Технологія включає очищення, водно теплову обробку, иліфування, сортування продуктів шліфування, воднотеплову обробку шліфованого ядра, змішування, плющення, сушіння та контроль готової продукиії. Завдяки відмінностям у характеристиках, особливо у формі зерна, первинна обробка голозерного вівса та голозерного ячменю проводиться без етапу фракціонування на двох паралельних технологічних лініях.

Досліджені зразки голозерного ячменю характеризувалися високою масовою часткою білку 14,6-15,8 \% та $\beta$-глюканів - 6,8-7,4\%, близькою з звичайним лущеним зерном масовою часткою жиру - 2,1-3,8 \% та крохмалю - 59,3-61,6\%, низькою масовою часткою золи 2,3-2,7 \%. Голозерний овес традиційно характеризувався високою масовою часткою жиру - 6,0-6,3 \%, білка 14,9-15,4\% та $\beta$-глюканів - 6,4-6,9\% та мав близькі до звичайного лущеного зерна масові частки крохмалю - 59,3-61,6\% та золи - 2,1-2,3\%. Шліфування зерна голозерного вівса та голозерного ячменю при зміні вологості (від 12 до $14 \%$ в залежності від режиму обробки дозволяє отримувати вихід цілого ядра 67-96\%.

Підвищення вмісту вологи в зерні вище 14 \% перед шліфуванням суттєво не змінює межі виходу цілого ядра, а шліфування зерна з низьким вмістом вологи (10,5\%) призводить до надмірного подрібнення та утворення 
значної кількості побічних продуктів та відходів у вигляді дрібних частинок подрібненого ядра $і$ борошения.Технологічно доцільною вологістю для шліфованого ядра голозерного вівса перед пропарюванням є $15 \%$, тиск пари - 0,10 МПа. При виробництві плющуеного ядра із голозерного ячменю технологічно дочільною вологістю ядра перед пропарюванням є $20 \%$, тиск пари 0,10 МПА. Обробка ядра затакого режиму дозволяє отримувати вихід плющеного ядра від 84 до $93 \%$.

Ключові слова: голозерний овес, голозерний ячмінь, крупа, пластівці, суміш круп та пластівців, режими переробки, схема переробки, хімічний склад.

1. Pomeranz, Y., \& Shands, H. L. (1974). Food uses of barley. Critical Reviews in Food Science \& Nutrition, 4(3), $377-394$.

2. Evdokhova, L.N., \& Rukshan, L.N. (2012). The use of barley flour to create a flour confectionery health improving orientation. Pratsi Tavriyskogo state agrotechnology university, (12, t. 2), 203-213.

3. Kurochkin, A. A., Shaburova, G. V., \& Novikov, V. V. (2006). Use of extruded barley in brewing. Beer and beverages, (5)., 16-17.

4. Pavlovskaya, N. E., Kostromicheva, E. V., Kuleshova, E., Gorkova, I. V., \& Gagarina, I. N. (2012). Barley source of antibiotics. Journal of Agricultural Science, 37 (4), 70-72.

5. Kroshko, GD (1998). Rules for organizing and maintaining the technological process at the mill factories. K .: WIPOL.

6. Pomeranz, Y. (1991) Functional Properties of Food Components. San Diego, CA: Academic Press

7. Kaukovirta-Norja, A., Wilhelmson, A., \& Poutanen, K. (2004). Germination: a means to improve the functionality of oat.

8. Hager, A. S., Taylor, J. P., Waters, D. M., \& Arendt, E. K. (2014). Gluten free beer-A review. Trends in Food Science \& Technology, 36(1), 44-54.

9. Schnitzenbaumer, B., Kaspar, J., Titze, J., \& Arendt, E. K. (2014). Implementation of commercial oat and sorghum flours in brewing. European Food Research and Technology, 238(3), 515-525.

10. Önning, G., Wallmark, A., Persson, M., Ảkesson, B., Elmståhl, S., \& Öste, R. (1999). Consumption of oat milk for 5 weeks lowers serum cholesterol and LDL cholesterol in free-living men with moderate hypercholesterolemia. Annals of Nutrition and Metabolism, 43(5), 301-309.

11. Gambuś, H., Gibiński, M., Pastuszka, D., Mickowska, B., Ziobro, R., \& Witkowicz, R. (2011). The application of residual oats flour in bread production in order to improve its quality and biological value of protein. Acta Scientiarum Polonorum Technologia Alimentaria, 10(3), 317-325.

12. Marshall, A., Cowan, S., Edwards, S., Griffiths, I., Howarth, C., Langdon, T., \& White, E. (2013). Crops that feed the world 9. Oats-a cereal crop for human and livestock feed with industrial applications. Food Security, 5(1), 13-33.

13. Eliasson, A. C. (2006). Carbohydrates in food. CRC press.

14. Chu, Y. (Ed.). (2013). Oats nutrition and technology. John Wiley \& Sons.

15. Hamaker, B. R. (Ed.). (2007). Technology of functional cereal products. Elsevier.

16. Sots, S.M. Evaluation of some technological factors of Ukrainian naked oats and barley affecting on its processing to food products - http://pscipub.com/Journals/Data/JList/Scientia\%20Agriculturae/2014/Volume\%208/Issue\%201/8.pdf

17. Yegorov, G.A. (1985) Tekhnologicheskiye svoystva zerna (Technological properties of the grain). - M.: Agropromizdat

18. Steele, K., Dickin, E., Keerio, M. D., Samad, S., Kambona, C., Brook, R., ... \& Frost, G. (2013). Breeding low-glycemic index barley for functional food. Field crops research, 154, 31-39.

19. Peltonen-Sainio, P., Kirkkari, A. M., \& Jauhiainen, L. (2004). Characterising strengths, weaknesses, opportunities and threats in producing naked oat as a novel crop for northern growing conditions.

20. Yalcin, E., Celik, S., Akar, T., Sayim, I., \& Koksel, H. (2007). Effects of genotype and environment on $\beta$-glucan and dietary fiber contents of hull-less barleys grown in Turkey. Food Chemistry.

21. Batalova, G. A. (2014). Prospects and results of selection of bare oats. Leguminous and cereal crops, (2 (10)).

22. Kolmakov, Yu. V., \& Aniskov, N. I. (2009). Evaluation and quality requirements for grain naked grains of barley. Agrarian Bulletin of the Southeast, (3), 21-23.

23. Rukshan, L.V., Matveeva, A.V., \& Vetoshkina, A.A. Technology products from bare barley. Electronic resource] .- access mode: http: // gendocs. com / docs / 7/6320/conv_3 / file3. pdf\# page 25.

24. Helm, C. V., \& Francisco, A. D. (2004). Chemical characterization of Brazilian hulless barley varieties, flour fractionation, and protein concentration. Scientia Agricola, 61(6), 593-597.

25. Yin, Y. L., Baidoo, S. K., Schulze, H., \& Simmins, P. H. (2001). Effects of supplementing diets containing hulless barley varieties having different levels of non-starch polysaccharides with $\beta$-glucanase and xylanase on the physiological status of the gastrointestinal tract and nutrient digestibility of weaned pigs. Livestock Production Science, 71(2-3), 97-107.

26. Gryaznov, A. A. (2015). Barley barley varieties in poultry feeding. Livestock and veterinary medicine, (2 (17)). Zhang, J. Functional barley rice noodle and making method thereof/J. Zhang, et al. // [Електронний ресурс]. -режим доступу: http://www.google.com/patents/CN102067965A?cl=en

Received 24.04.2019.

Reviewed 13.05.2019
Revised 10.06.2019

Approved 03.09.2019.

Cite as Vancouver Citation Style

Sots S., Kustov I., Kuzmenko Y. Some features of barley and oats processing. Grain Products and Mixed Fodder's, $2019 ; 19$

(3): 34-40. DOI: https://doi.org/

Cite as State Standard of Ukraine 8302:2015

Some features of barley and oats processing / Sots S.et al. // Grain Products and Mixed Fodder's. 2019. Vol. 19, Issue 3. P. 3440. DOI: https://doi.org/

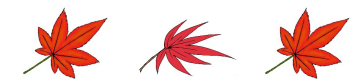

